\title{
A clinical case of familial hemophagocytic lymphohistiocytosis
}

\begin{abstract}
Tatiana A. Bykova, Varvara N. Ovechkina, Anna A. Osipova, Andrey V. Kozlov, Alexander L. Alyanskiy, Elena V. Semenova, Ludmila S. Zubarovskaya, Boris V. Afanasyev

R. Gorbacheva Memorial Research Institute of Children Oncology, Hematology and Transplantation; Department of Hematology, Transfusiology and Transplantology, The First St. Petersburg State I.Pavlov Medical University, St. Petersburg, Russia
\end{abstract}

Dr. Tatiana A. Bykova, PhD, R. Gorbacheva Memorial

Research Institute of Children Oncology, Hematology and

Transplantation, The First St. Petersburg State I. Pavlov

Medical University, L.Tolstoy St 6-8, 197022, St. Petersburg,

Russia
Phone: +7 (905) 2076776

E-mail: dr.bykova@mail.ru

Citation: Bykova TA, Ovechkina VN, Osipova AA et al. A clinical case of familial hemophagocytic lymphohistiocytosis. Cell Ther Transplant 2019; 8(1): 54-57.

\section{Summary}

Familial hemophagocytic lymphohistiocytosis (hemophagocytic syndrome) is a rare hereditary disease, characterized by dysregulation of the immune response, leading to the proliferation and activation of histiocytes, phagocytosis of peripheral blood cells. Timely diagnostics, specific combined immunosuppressive therapy and chemotherapy followed by allo-HSCT significantly increase the chances for a favorable outcome. We are presenting a case of family hemophagocytic lymphohistiocytosis associated with UNC13D mutation which was found in three siblings who exhibited quite different course of the disease and clinical prognosis.

\section{Keywords}

Familial hemophagocytic lymphohistiocytosis, hemophagocytic syndrome, hematopoietic stem cell transplantation.

\section{Introduction}

Hemophagocytic lymphohistiocytosis (HLH) is a common name for a number of potentially fatal inborn and acquired diseases, which are characterised by the changes in the immune response regulation, leading to uncontrolled proliferation of cytotoxic T-lymphocytes and macrophages, systemic inflammation. Due to the lack of specific clinical features and laboratory data, long-lasting fever, unclear cytopenias, unexplained liver failure, and elevated inflammation markers should lead to the suspicion for HLH.

Our case presentation was aimed for demonstration of different clinical pattern in HLH associated with the UNC13D genetic mutation.

\section{Case presentation}

\section{Sibling 1}

The patient was from a family without known hereditary disorders. A girl was born after the second full-term non-complicated pregnancy. Perinatal period proceeded without any specific features. Physical development was to the age until 2.4 years old, when a systemic disorder has manifested with high fever $\left(40.5^{\circ} \mathrm{C}\right)$ and lymphadenopathy. Despite the ongoing therapy with interferon and antibacterial treatment, the fever lasted for 14 days, and lymphadenopathy was presented by enlarged cervical lymph node group $(<2 \mathrm{~cm}$ in size) and inguinal nodes $(<1.5 \mathrm{~cm})$. Hepatomegaly and enlarged spleen were also registered (respectively, to $2.0 \mathrm{~cm}$, and 1.5$2.0 \mathrm{~cm}$ ). Clinical blood counts showed mild anemia, neu- 
tropenia, lymphocytosis, plasmacytosis, thrombocytopenia. PCR virological testing showed activation of Epstein-Barr virus (EBV) and cytomegalovirus (CMV) (blood).

The primary disorder was initially diagnosed as severe acute infectious mononucleosis with liver damage. Antiviral therapy with intravenous immunoglobulins was started. However, the patient's condition worsened due to persistent fever up to $40.5^{\circ} \mathrm{C}$, progressing hepatosplenomegaly, pancytopenia, hemorrhagic syndrome and oedema. Biochemical liver test panel showed hypoalbuminemia, hypofibrinogenemia, increased serum bilirubin (both direct and indirect fractions), enhanced ALT, AST, and GGTP activities. Hypertriglyceridemia and increased serum ferritin levels were also present.

On the basis of typical clinical picture and laboratory criteria, a hemophagocytic lymphohistiocytosis (HLH) was suspected [1].

Morphological study of bone marrow aspirate has revealed specific forms of phagocytizing monocytes with engulfed mature red blood cells in their cytoplasm. The cerebrospinal fluid protein test was $0.6 \mathrm{~g} / \mathrm{l}$, lymphocytic cytosis $-32 / 3$. Cytogenetic study of the bone marrow cells showed no abnormalities.

DNA sequencing of selected amplicons of known HLHassociate genes, i.e., STX11 (exons 1-2), STXBP2 (exons 1 to 19 ), PRF1 (exons 1 to 3 ) and adjacent intronic segments did not reveal any homozygous mutations. In STXBP2 gene (exon 18), the analysis has shown an ATA $\rightarrow$ GTA substitution in c.1609an (Ile537Val) in heterozygous state. This polymorphism is rather common in population (0.264). Hence, the data from Sanger DNA sequencing analysis showed a heterozygous state for STXBP2 and UNC13D gene mutations which indirectly supported the HLH diagnosis.

Due to suspected primary HLH and rapid clinical progression of disease, the HLH-94 protocol therapy with VP-16, dexamethasone, Cyclosporin $\mathrm{A}$, and intratecal cytostatic therapy was started before receiving the genetic test results. According to the HLA typing data, the siblings were haploidentical.

Partial clinical response (apyrexia, lymph node size reduction, normalization of liver function) was achieved within 4 weeks after initiating the therapy, but the CMV reactivation associated with the disease progressed followed by fatal outcome at the age of 2 years 7 months.

\section{Sibling 2}

A boy from the $4^{\text {th }}$ normal full-term pregnancy, without specific symptoms during postnatal period. At the age of 1.3 y.o., the child presented with fever which lasted for up to 8 days. Viral infection was suggested as a primary diagnosis, and symptomatic therapy was started. Positive dynamics was achieved, but the sub-febrile body temperature still persisted. Cytopenia was detected in routine blood counts (total leucocyte count $-7.0 \times 10^{9} / 1$, absolute neutrophil count $-0.42 \times 10^{9} / 1$, platelet count $\left.-60 \times 10^{9} / 1\right)$. The serum ALT and AST levels exceeded five-fold the normal values. A differential diagnosis was made between infectious mononucleosis, viral hepatitis, and Yersinia infection.
The laboratory tests have shown pancytopenia, atypical mononuclear cells (blood); hypofibrinogenemia; hypertriglyceridemia; serum ferritin level within normal limits; the viral hepatitis markers (HAV, HBV, HCV) were negative. PCR tests for HSV type 6 (blood) were positive, as well as EBV DNA was found in saliva. Hepatomegaly was up to +2.0 $\mathrm{cm}$, and splenomegaly, up to $+3.0 \mathrm{~cm}$.

Despite the symptomatic therapy the patient showed further cytopenia, febrile fever, lymphoproliferative syndrome without progression. Hemophagocytosis was not detectable in the bone marrow aspirate and cerebrospinal fluid.

Like as in sibling 1, a direct gene sequencing showed heterozygous mutation found in exon 31 of the UNC13D gene, i.e., single-nucleotide deletion (c.3082delC) and duplication (c.3037dupG) in the same exon, without reported associations with any inherited conditions.

The patient underwent specific therapy according to the HLH-94 protocol with achievement of a complete response by the end of initial treatment course. The prolonged therapy was continued over 9 weeks (dexamethasone pulse treatment at $10 \mathrm{mg} / \mathrm{m}^{2}$ for 3 days every second week and VP-16 infusions $150 \mathrm{mg} / \mathrm{m}^{2}$ every alternating second week with daily oral CSA), the clinical remission still persisted.

The patient and his sister were HLA-haploidentical. An unrelated donor was found in the International Donor Registry (9/10 compatibility for the main HLA loci, with only mismatch in locus C) and used for HSCT in this case.

A myeloablative reduced-toxicity conditioning with Treosulfan, Fludarabin and Thiotepa,was chosen for hematopoietic stem cell transplantation (HSCT). GvHD prophylaxis consisted of post-transplant cyclophosphamide, tacrolimus, and Cellsept. The patient has tolerated the conditioning regimen without significant associated toxicity. Engraftment was achieved on the $\mathrm{D}+27$ post-transplant. The follow-up period after allo-HSCT is one year. The hematopoietic graft functions satisfactorily with engraftment at the level of complete donor chimerism, there is no dependence on blood transfusions, with persisting remission of the disease.

\section{Sibling 3}

In view of the family history, the eldest child (sister) in the family was also observed. A mutation in the heterozygous state was also detected in the UNC13D gene by Sanger sequencing analysis. At the time of the survey, the girl was 12 years old. The physical development of the child is age appropriate. No signs of HLH have been shown so far, thus suggesting a sufficient phenotypic heterogeneity among the siblings observed.

\section{Discussion}

HLH is a severe clinical syndrome of the immune system, requiring early diagnosis, which allows combined immunosuppressive and chemotherapy to be started in time and may be followed by allo-HSCT, thus significantly increasing the chances for a favorable outcome of the disease [2].

The primary, genetically determined cases of HLH evolve as a result of genetically determined defect of the cellular 
cytotoxicity, and due to secondary hemophagocytic syndrome. The incidence of primary HLH is 1 in 50.000 newborns per year. Up to $70-80 \%$ of the primary HLH cases are diagnosed over the first year of life, whereas $20 \%$ manifest at the age of $>3$ years [3]. Secondary HLH may be associated with infectious, systemic autoimmune, malignant diseases and hereditary metabolic errors, depending on the distinct causal factors (Table 1).

Clinically, HLH is manifested by prolonged fever refractory to antimicrobial therapy; progressive cytopenia; lymphoproliferative, oedemas and hemorrhagic syndromes; hepatic dysfunction; symptoms of damage to the central nervous system (irritability, convulsions, meningeal symptoms, altered consciousness). Infections, mostly caused by herpesviruses, seem to be the main trigger leading to the HLH manifestations [7]. In the absence of specific therapy, the disease progresses rapidly and may end fatally. Sometimes, however, it may have a chronic, relapsed clinical course.

Appropriate clinical findings in HLH are non-specific, despite the severity of the manifestations. Therefore, it is possible to establish the diagnosis only on the basis of some characteristic laboratory tests. To establish the HLH diagnosis, at least 5 of 8 diagnostic criteria proposed by the International Society of Histiocytosis should be present in the patient, as follows: fever over 38.5 with a duration of at least 7 days, splenomegaly $(>3.0 \mathrm{~cm}$ ), bicytopenia (hemoglobin $<90 \mathrm{~g} / \mathrm{l}$, platelet count $<100 \times 10^{9} / \mathrm{l}$, neutrophil count $\left.<1 \times 10^{9} / \mathrm{l}\right)$, hypertriglyceridemia $(>2.0 \mathrm{mmol} / \mathrm{L})$, and/or hypofibrinogenemia $(<1.5 \mathrm{~g} / \mathrm{L})$, increased serum ferritin (more than $500 \mu \mathrm{g} / \mathrm{L}$ ), decreased activity of peripheral NK cells, soluble CD25+ over $2500 \mathrm{U} / \mathrm{L}$, evidence of hemophagocytosis in the bone marrow, lymphatic nodes, cerebrospinal fluid [1].

In young patients, HLH should be differentiated from sepsis, generalized perinatal infections, Wiscott-Aldrich syndrome, acute leukemia, juvenile myelomonocytic leukemia, histio- cytosis originating from Langerhans cells, autoimmune lymphoproliferative syndrome. In older patients, hemophagocytic syndrome also needs to be differentiated from sepsis, hemoblastosis, viral hepatitis, viral encephalitis.

Early onset of the disease ( $1^{\text {st }}$ year of life), family history (related marriage, sibling death in infancy), persistence of cellular cytotoxicity defects after achieving clinical/laboratory remission, recurrence of the disease, may be indicative for its hereditary nature. The final diagnosis of primary HLH is generally supported by identified mutations in one of candidate genes (PRF1, MUNC13D, STX11, STXBP) [6].

All the patients with suspected primary HLH should receive combined immunosuppressive chemotherapy to control systemic inflammation and prevent irreversible organ damage. Detection of pathogenic mutations is currently a necessary diagnostic criterion for predicting the time of onset and severity of clinical manifestations in primary forms of HLH, but these may be present and also occur in patients without signs of disease, as confirmed in one of the largest studies of HLH patients from Italy [8].

In the case of asymptomatic carriage of a potentially pathogenic mutation, the patient management strategies are determined by the nature of presumed defect. E.g., the patients with UNC13D mutation are kept under dynamic observation, while PRF1 and RAB27A mutations have an unfavorable prognosis, and the patients who underwent allo-HSCT prior to the development of clinical HLH symptoms have better survival rates [9].

Allogeneic transplantation of hematopoietic stem cells (alloHSCT) is indicated in cases of proven primary HLH. Allo-HSCT is a preferable option in remission of the disease, but the absence of remission is not a contraindication for it. If planning a related allo-HSCT, it is necessary to make sure that the potential donor (sibling) who has no phenotypic features of the disorder doesn't suffer from familial HLH.

\section{Table 1. Causal and pathogenetic factors for secondary HLH $[4,5,6]$}

\begin{tabular}{|l|l|}
\hline Infections & $\begin{array}{l}\text { Viruses: EBV, CMV, parvovirus B19, herpesviruses 1, 2, 6, 8, Herpes zoster, Influenzavirus } \\
\text { HIN1, parainfluenza III, HIV } \\
\text { Bacteria: Mycobacterium spp, Mycoplasma pneumoniae, Brucella spp, Chlamydia psittaci, } \\
\text { Mycoplasma pneumonia, Salmonella typhii, Rikkettsia, Leptospira Spirocheta pallidum } \\
\text { Fungi: Histoplasma spp, Candida albicans, Aspergillus, Criptococcus, Histoplasma } \\
\text { capsulatum, Penicillium marneffei, P. carinii, Trychophyton beigelii } \\
\text { Parasites: Leishmania spp, Babesia, Plasmodium falciparum, Plasmodium vivax, } \\
\text { Toxoplasma gondii }\end{array}$ \\
\hline Malignancies & $\begin{array}{l}\text { Various types of lymphoma (non-Hodgkin: B cell; anaplastic large cell lymphoma), } \\
\text { acute leukemia, germ-cell tumors }\end{array}$ \\
\hline Autoimmune disorders & $\begin{array}{l}\text { Systemic lupus erythematosus, juvenile dermatomyositis, periarteritis nodosa, } \\
\text { systemic juvenile rheumatoid arthritis }\end{array}$ \\
\hline Acquired immunodeficiency & HIV/AIDS, organ transplantation, HSCT \\
\hline Inherited storage diseases & $\begin{array}{l}\text { Biotinidase deficiency, lysinuria, galactosemia, multiple sulfatase deficiency, Gaucher } \\
\text { disease, Pearson syndrome }\end{array}$ \\
\hline
\end{tabular}




\section{References}

1. Henter JI, Horne A, Aricó M, Egeler RM, Filipovich AH, Imashuku S, Ladisch S, McClain K, Webb D, Winiarski J, Janka G.. HLH-2004: diagnostic and therapeutic guidelines for hemophagocytic lymphohistiocytosis. Pediat Blood Cancer. 2007;48(2):124-131.

2. Janka GE, Lehmberg K. Hemophagocytic syndromes an update. Blood Rev. 2014: 2014;28(4):135-142.

3. George MR. Hemophagocytic lymphohistiocytosis: review of etiologies and management, J Blood Med. 2014;5:69-86.

4. Contino A, Trombatore G, Timeus F. Hemophagocytic lymphohistiocytosis in pediatric patients: a review. J Blood Disord Symptoms Treat. 2018; 2(1): 011.

5. Maschan MA, Novichkova GA, Federal Clinical Guidelines for the Diagnosis and Treatment of Hemophagocytic Lymphohistiocytosis, 2014 (in Russian).

6. Zhang K, Filipovich AH, Johnson J, Marsh RA, Villanueva J, Hemophagocytic lymphohistiocytosis, familial, GeneReviews [Internet]. Seattle (WA). 2006; Mar 22 [updated 2013 Jan 17].
7. Brisse E, Wouters CH, Andrei G, Matthys P. How viruses contribute to the pathogenesis of hemophagocytic lymphohistiocytosis. Front Immunol. 2017 Sep 7;8:1102. doi: 10.3389/fimmu.2017.01102.

8. Cetica V, Sieni E, Pende D, Danesino C, De Fusco C, Locatelli F, Micalizzi C, Putti MC, Biondi A, Fagioli F, Moretta L, Griffiths GM, Luzzatto L, Arico M. Genetic predisposition to hemophagocytic lymphohistiocytosis: Report on 500 patients from the Italian registry, J Allergy Clin Immunol. 2016;137(1):188-196.e4

9. Lucchini G, Marsh R, Gilmour K, Worth A, Nademi Z, Rao A, Booth C, Amrolia P, Silva J, Chiesa R, Wynn R, Lehmberg K, Astigarraga I, Gungor T, Stary J, Moshous D, Ifversen M, Zinn D, Jordan M, Kumar A, Yasumi T, Vey P, Rao K. Treatment dilemmas in asymptomatic children with primary haemophagocytic lymphohistiocytosis. Blood, 2018;132(19):2088-2096.

\title{
| Клинический случай семейного гемофагоцитарного лимфогистиоцитоза
}

\author{
Татьяна А. Быкова, Варвара Н. Овечкина, Анна А. Осипова, Андрей В. Козлов, Александр Л. Алянский, \\ Елена В. Семенова, Людмила С. Зубаровская, Борис В. Афанасьев \\ НИИ детской онкологии, гематологии и тнрансплантологии им. Р. М. Горбачевой, кафедра гематологии, \\ трансфузиологии и трансплантологии, Первый Санкт-Петербургский государственный медицинский университет \\ им. И. П. Павлова, Санкт-Петербург, Россия
}

\section{Резюме}

Семейный гемофагоцитарный лимфогистиоцитоз (гемофагоцитарный синдром) - редкое наследственное заболевание, в основе которого лежит нарушение регуляции иммунного ответа, приводящее к пролиферации и активации гистиоцитов, фагоцитозу клеток периферической крови. Своевременная диагностика и специфическая комбинированная иммуносупрессивная и химиотерапия с последующей алло-ТГСК значительно увеличивают вероятность благоприятного исхода болезни.
Описывается случай семейного гемофагоцитарного лимфогистиоцитоза у трех сибсов, который был ассоциирован с мутацией $U N C 13 D$ в гетерозиготной форме. Экспрессия клинической симптоматики у сибсов была различной как по характеру течения, так и по прогнозу заболевания.

\section{Ключевые слова}

Семейный гемофагоцитарный лимфогистиоцитоз, гемофагоцитарный синдром, алло-ТГСК. 